УДК 314.151.3-054.72(=163.42)“196/197“(046)

$323.1(=163.42)(497.1) " 196 / 197 “$

Dr Petar DRAGIŠı́́

Institut za noviju istoriju Srbije

\title{
ANALIZA HRVATSKE DRŽAVE (MAJ-JUN 1969) - ORGANA HRVATSKOG NARODNOG ODBORA*
}

\begin{abstract}
APSTRAKT: U radu je analiziran sadržaj broja 171-172 (maj-jun 1969) lista Hrvatska država. Istraživanje predstavlja pokušaj da se ispitivanjem tekstova objavljenih u ovom listu utvrde ključni stavovi njenog izdavača - Hrvatskog narodnog odbora, odnosno njegovog lidera Branka Jelića. S obzirom na značaj ove organizacije u političkom životu desničarske hrvatske dijaspore, rad može pomoći u rekonstrukciji ideja i pogleda hrvatske političke dijaspore krajem 60-ih godina 20. veka.
\end{abstract}

Ključne reči: Hrvatska država, Hrvatski narodni odbor, hrvatska emigracija, Jugoslavija, UDBA

Otpor novouspostavljenom komunističkom poretku u Jugoslaviji, te strah od posledica učešća u ratu na poraženoj strani proizveli su krajem Drugog svetskog rata veliki emigracioni talas, koji su činili pripadnici i saradnici poraženih snaga. Bežeći od novouspostavljenog režima u Jugoslaviji spas su potražili na Zapadu - u zemljama Zapadne Evrope, kao i u prekookeanskim državama. Korpus političke emigracije jačao je i tokom posleratnih decenija, prilivom novih migranata iz Jugoslavije, nezadovoljnih političkim idejama i životom u Titovoj zemlji.

Lišena mogućnosti da direktno utiče na političke procese u Jugoslaviji, jugoslovenska politička emigracija nije, ipak, bila pasivni posmatrač događanja u bivšoj domovini. Emigranti su odbijali da se pomire sa ishodom rata i nastavili

* Rad je nastao u okviru projekta Tradicija i transformacija - istorijsko nasleđe i nacionalni identiteti u Srbiji u 20. veku, (№ 47019), koji finansira Ministarstvo prosvete i nauke Republike Srbije. 
su svoju borbu protiv jugoslovenskog režima. Upornim propagandnim akcijama stalno su nastojali da za svoje ciljeve animiraju javnost u zemljama u kojima su pronašli zaštitu, ali i da svoje ideje distribuiraju u samoj Jugoslaviji. Delovanje emigranata nije se, međutim, ograničavalo samo na propagandne aktivnosti. Ekstremnije grupe hrvatskih i srpskih političkih emigranata neretko su pribegavale i nasilnim akcijama u pokušaju da destabilizuju komunistički režim.

Ideje hrvatskih političkih emigranata zastupale su krajem šezdesetih i početkom sedamdesetih godina brojne emigrantske organizacije, među kojima su prema procenama jugoslovenskih vlasti najuticajnije bile: Hrvatski oslobodilački pokret, Hrvatski narodni odbor ( $\mathrm{HNO}$ - jelićevci), Hrvatski narodni odbor (HNO - luburićevci), Hrvatsko revolucionarno bratstvo, Hrvatska republikanska stranka i Hrvatska seljačka stranka. Organizacije hrvatskih političkih emigranata su bile razgranate, obuhvatajući filijale u svim zemljama sa brojnom hrvatskom dijasporom. ${ }^{1}$

Vodeće organizacije hrvatskih emigranata i istaknuti politički angažovani predstavnici hrvatske dijaspore bili su pod budnom prismotrom jugoslovenskih obaveštajnih službi. Jugoslovenska tajna policija je nastojala da ograniči delovanje hrvatskih političkih emigranata, pri čemu se posezalo i za radikalnim sredstvima. Tokom decenija posle Drugog svetskog rata jugoslovenski režim je likvidirao više uticajnih predstavnika hrvatske političke dijaspore. Hrvatska emigracija je, međutim, preživela snažne pritiske jugoslovenskih vlasti, pa su se već početkom 90-ih godina vodeći hrvatski emigranti direktno uključili u politički život nove hrvatske države i igrali značajnu ulogu u ratovima na prostoru bivše Jugoslavije.

Ekstremni krugovi hrvatske emigracije su u sukobu sa jugoslovenskim režimom pribegavali i nasilnim sredstvima, koja su se najčešće svodila na planiranje diverzija i napade na članove jugoslovenskih diplomatskih misija u inostranstvu. Ipak, hrvatska emigracija se u borbi sa Brozovim režimom služila i manje radikalnim sredstvima, poput rasturanja letaka ili izdavanja časopisa u kojima je oštro kritikovana jugoslovenska vlast. Prema jugoslovenskim podacima s početka 70-ih godina, jugoslovenski (ne samo hrvatski) politički emigranti izdavali su oko 150 listova, čiji je ukupan tiraž procenjivan na oko 400.000 primeraka. $^{2}$

Rad Hrvatskog narodnog odbora, sa sedištem u Berlinu i Minhenu, obuhvatao je, prema navodima iz analize Državnog sekretarijata za inostrane poslove iz juna 1970. godine, aktivnosti ,na političko-propagandnom planu“, podršku akcijama „ekstremnog dela emigracije“, kao i pokušaje povezivanja sa ,,istomišljenicima u zemlji“،. Organizacija, kojom je rukovodio uticajni hrvatski emigrant

\footnotetext{
AJ, Socijalistički savez radnog naroda Jugoslavije (142), f. 474, Državni sekretarijat za inostrane poslove, Problemi vezani za aktivnost političke emigracije i potreba stalne i koordinirane protuakcije, 5. 6. 1970.

2 Isto.
} 
iz Zapadnog Berlina Branko Jelić, izdavala je i list Hrvatska država. U pomenutom izveštaju jugoslovenskog Državnog sekretarijata za inostrane poslove navedeno je da je Hrvatska država „donedavno“ izlazila jednom mesečno sa tendencijom da preraste u nedeljnik ,koji bi donosio što više aktuelnosti u vezi sa zemljom“.”3

Analiza broja Hrvatske države za maj-jun 1969. godine ima za cilj pokušaj rekonstrukcije ideja i stavova jedne od značajnijih organizacija hrvatskih političkih emigranata. Značaju ovog istraživanja posebno doprinosi činjenica da je navedeni broj Hrvatske države štampan u periodu zaoštravanja političkih tenzija u Jugoslaviji, kao i radikalizacije delovanja hrvatske političke emigracije.

Sadržajem prvih strana Hrvatske države dominiraju tekstovi o proslavi 10. travnja. ${ }^{4} \mathrm{Na}$ naslovnoj strani je u tekstu „Proslave hrvatske državne nezavisnosti“" navedeno da je jubilej NDH obeležen u Minhenu, Geteborgu, Klivlendu, Čikagu, Torontu, Buenos Ajresu. Posebna pažnja posvećena je opisu proslave u Klivlendu, budući da je ona održana uprkos pokušajima tamošnje srpske zajednice da nagovori vlasti da zabrane obeležavanje 10. travnja. ${ }^{5}$ Navedeno je da su proslavi u Buenos Ajresu, pored hrvatskih emigranata iz Argentine, prisustvovali i hrvatski iseljenici iz Urugvaja i Čilea. ${ }^{6}$

Aprilske proslave jubileja NDH pružile su vodećim ličnostima hrvatske dijaspore priliku da javno izlože svoje političke i ideološke stavove. Centralno mesto u analziranom broju Hrvatske države, razumljivo, zauzima govor njenog izdavača i lidera Hrvatskog narodnog odbora Branka Jelića održan na proslavi 10. travnja u Minhenu. Sadržaj njegovog govora nije bitan samo za razumevanje ideja i stavova Hrvatskog narodnog odbora, na čijem se čelu nalazio, već baca i posebno svatlo na ideologiju čitave hrvatske političke dijaspore, budući da je Jelić u to vreme bio jedan od njenih najuticajnijih predstavnika.

Veći deo svog govora Branko Jelić je posvetio analizi statusa Hrvatske i hrvatskog naroda u Jugoslaviji, pri čemu je akcenat stavljen na podređen položaj jugoslovenskih Hrvata u odnosu na druge jugoslovenske narode. Podvučena je navodna srpska prevlast u Jugoslaviji, kao i ekonomska diskriminacija Hrvatske, odnosno inferiornost Hrvatske u odnosu na ostale jugoslovenske republike, pri čemu je naglašeno „srbijansko izrabljivanje“ Hrvatske. Jelić je u svom govoru podvukao i navodnu diskriminaciju hrvatskih kadrova u ondašnjoj jugosloven-

\footnotetext{
Isto.

4 Dan proglašenje NDH.

5 „Proslava hrvatske državne nezavisnosti“, Hrvatska država, maj-jun 1969. Prema navodima Hrvatske države u dopisu Srpske verske zajednice Sveti Sava stajalo je sledeće: „Oni koji su Vas (gradonačelnika Klivlenda) prevarili da proglasite 10. travanj kao dan Hrvatske Nezavisnosti, njihove su ruke poprskane krvlju tisuća nevinih i bespomoćnih žrtava, ubijenih na najnečovečniji način, kojeg svet poznaje. Dozvoliti im da stupaju glavnim trgom i da slave svoju nezavisnost bilo bi isto kao kada bi Vi dozvolili članovima razbojničke Nazi partije da stupaju Vašim gradom sa zastavama sa kukastim križom, slaveći uspostavu Hitlerovog Trećeg Reicha."

6 Isto.
} 
skoj administracij: „U kojem se opsegu vrši gospodarska pljačka u ovim ostacima ostataka nekadašnjeg slavnog kraljevstva Hrvata nažalost je hrvatskoj javnosti nepoznato, jer to Beograd strogo taji, međutim će i to s vremenom doći na vidjelo. Vidna posljedica takovog stanja se odražava u hrvatskim krajevima u formi nezaposlenosti, pa naši hrvatski radnici pune evropske tvornice i gradilišta, a ne stanovništvo iz takozvanih nerazvijenih krajeva te države. Sva važnija mjesta po Hrvatskoj zauzimaju Srbi, polupismeni i na brzu ruku kroz dvojbena sveučilišta okićeni raznim akademskim titulama. Oni obavljaju tihu i sistematsku imperijalističku kolonizaciju hrvatskih zemalja. To je razlog, da inače plodni hrvatski narod ima najniži prirodni prirast stanovništva na svijetu sa cca $5 \%$. Osim toga se želi naš jezik zatrti, srbijanštinama iznakaziti putem štampe, krugovala, televizije, vojske i škole. Brojčano stanje javnih službenika Hrvata u administraciji, sudstvu i radničkim organizacijama je u nesrazmjeru sa brojem hrvatskog stanovništva i sa ekonomskom snagom hrvatskih krajeva (...) Na početku prvog svjetskog rata mi smo imali u staroj dunavskoj monarhiji preko 100 generala Hrvata i na tri fronte su Hrvati bili zapovjednici, dok u Jugoslaviji nije bilo do god.(ine) 1928. niti jednog generala Hrvata. Prema tome ja vas pitam, gdje postoji ili je postojala takova kolonija, izrabljivana sa strane imperialista; gdje postoji jedan narod, koga se nastoji biološki iskorijeniti, kao što je danas slučaj sa Hrvatskom i hrvatskim narodom?"“7

Radikalna i jednostrana kritika statusa Hrvata i Hrvatske u socijalističkoj Jugoslaviji nije bila jedina tema Jelićevog govora u Minhenu. Obeležavanje jubileja NDH jedan od ideologa hrvatske političke emigracije iskoristio je i za predstavljanje svoje vizije rešenja „hrvatskog pitanja“. Centralnu tačku Jelićeve projekcije predstavljalo je distanciranje od Srbije i stvaranje nezavisne hrvatske države. Kao argument za neophodnost „razlaza“ sa Srbijom, Jelić je osim već podvučene podređenosti Hrvata u Jugoslaviji naveo i postojanje značajnih kulturnih i istorijskih razlika između Hrvata i Srba i oštro kritikovao one Hrvate koji nisu delili njegov jugoskepticizam: „Koji razlog onda može voditi još neke, da Hrvatska ostane u zajednici sa Srbijom? Takovu politiku osim Srbijanca, koji su korisnici ovoga stanja i koji žele na ruševinama Hrvatske i nakon propasti hrvatskog naroda u našoj zemlji ostvariti Veliku Srbiju, mogu podupirati samo kreteni, nacionalni uškopljenici i plaćene izdajice. Svi oni, koji pod bilo kakovom izlikom nastoje tražiti opravdanje za svoju izdajničku rabotu, vrijedni su samo prezira hrvatskog naroda.“

Širokom krugu onih koje je smatrao protivnicima hrvatskih nacionalnih interesa Jelić je priključio i delove hrvatskog klera, ne propustivši pri tom da podvuče svoju odanost Katoličkoj crkvi. U svom govoru Jelić, međutim, nije naveo imena onih čije je „hrvatstvo“ “javno osporio: „Čak što više, neke kukavički poglavice, koje se kreću na liniji najmanjeg otpora, zabranjuju hrvatskom sve-

„Stvoriti svoju državu ili propasti“, Hrvatska država, maj-jun 1969. 
ćenstvu borbu rame uz rame sa svojom hrvatskom braćom radi očuvanja hrvatske narodne budućnosti u ludoj nadi da, i ako nestane Hrvatske, da će oni moći održati se kao poglavice i predstavnici crkve. Ovakova politika, bila vođena od Vatikana ili od pojedinih nadbiskupa ili biskupa, ne samo da je jadna i kukavička, nego je osim toga i izdajnička i u najmanju ruku nerazborita. ${ }^{68}$

Elaboraciju svojih pogleda na hrvatsko nacionalno pitanje u govoru na proslavi 10. travnja Branko Jelić je završio naglašavanjem multikonfesionalne strukture Hrvatske, pledirajući za ravnopravnost svih vera u budućoj nezavisnoj hrvatskoj državi. Upadljiva je pritom činjenica da je ideolog Hrvatskog narodnog odbora muslimansko i pravoslavno stanovništvo Hrvatske posmatrao kao deo hrvatskog etnosa: „Mi ćemo u hrvatskoj državi poštivati sve vjere. Mi smo Hrvati većinom katolici i muslimani. Jedna velika skupina pripada i pravoslavnoj crkvi, od kojih se dobar dio sve do prije par decenija osjećao Hrvatima. Najbolji su dokaz tome obitelji Preradovići, Harambašići, Borojevići, Ogrizovići, Kokotovići, Zastavnikovići i hiljade drugih pravoslavnih familija, koji su bili stubovi hrvatstva (...) Veliki dio naših pravoslavaca je vlaškog porijekla, a najmanji srpskoga. Bez obzira, što su oni bili i kako su se osijećali, ako kod njih bude lojalnosti prema hrvatskom narodu i hrvatskoj državi, oni moraju biti u svemu ravnopravni sa ostalim svim građanima drugih vjeroispovjesti. “9

$\mathrm{Na}$ istoj strani Hrvatske države nalazi se i tekst povodom smrti Vjekoslava Maksa Luburića, koji je ubijen u Španiji 20. aprila 1969. godine. ${ }^{10}$ Anonimni autor teksta je bio suočen sa teško rešivim problemom. Radilo se o pokušaju relativizovanja zločina komandanta logora Jasenovac. U članku nije negirana Luburićeva odgovornost za zločine počinjene u NDH, ali su istovremeno podvlačeni zločini druga dva učesnika u građanskom ratu na tlu Jugoslavije od 1941. do 1945. - četnika i partizana. Čitaocu je tako otvoreno sugerisano da su Luburićevi (i u širem smislu ustaški) zločini u Drugom svetskom ratu samo posledica četničkih i partizanskih zločina. Iako to nije neposredno zaključeno, primetno je nastojanje da se ustaški ekstremizam predstavi kao oblik samoodbrane: „Jer, konačno, nama Hrvatima je bio potpuno nepoznat politički teror, dok nije bio unešen u naše

\footnotetext{
Isto.

Isto.

10 Komandant logora Jasenovac Vjekoslav Maks Luburić do svoje smrti predvodio je Hrvatski narodni odbor, čije se sedište do njegove smrti nalazilo u Španiji. Posle Luburićevog ubistva 1969. godine najuticajniji ogranak organizacije nalazio se u Kanadi. U analizi Državnog sekretarijata za inostrane poslove iz 1970. godine Luburićeva organizacija je označena kao poluvojnička organizacija. Organizacija je imala filijale i u Saveznoj Republici Nemačkoj, Švedskoj, Francuskoj, SAD-u i u Australiji. Prema navodima iz izveštaja, organizacija je bila orijentisana na „terorističke i političko-propagandne akcije“, a bila je sastavljena od „najekstremnijih ustaških emigranata, oficira i vojnika“. Luburićeva organizacija je u Španiji imala štampariju i izdavala listove Odbrana i Drina. AJ, Socijalistički savez radnog naroda Jugoslavije (142), f. 474, Državni sekretarijat za inostrane poslove, Problemi vezani za aktivnost političke emigracije i potreba stalne i koordinirane protuakcije, 5. 6. 1970.
} 
krajeve zlosretnim sticajem političkih prilika, kada smo se našli u jednoj državi sa Srbijom. Srpski četnici su počeli sa pokoljima nedužnih Hrvata u god. 1941. i njihova zločinstva i okrutnosti su po čitavoj zemlji vapile za osvetom. A što da se govori o masovnim nedjelima komunističkih partizana? Njihovo ratovanje i vladanje poslije rata predstavlja neprekinuti lanac zločina, koji još traju do danas (...) Što su onda Luburićevi eventualni sporadički i nesistematski ekcesi, usporedivši ih sa mamutskim krvoprolićima Tita, Rankovića i ostalog srpsko-komunističkog društva." "11

„Sporadični i nesistematski ekcesi“ se u tekstu pripisuju i Luburićevom karakteru. Konstatuje se da je Luburić bio ,neiskusan, nagao i neustrašiv fanatik hrvatske države“, odnosno da nije bio ,najprikladnija osoba da u tom spletu najraznovrsnijih utjecaja u vrtlogu nacionalnih strasti u svom djelovanju zadrži mjeru, koja je bila potrebna da se hrvatsko ime i prestiž hrvatske države ne identificira sa običnim zločinom“. To je i jedino što je autor članka zamerio Luburiću, kome u zaključku teksta pripisuje „osobno poštenje, materijalnu nezainteresovanost, odvažnost i veliko hrvatsko rodoljublje“. ${ }^{12}$

Tematski povezan sa pomenutim tekstom je članak Luburićevog saradnika Ž. Bebeka pod naslovom „Lanac UDB-inih zločina se nastavlja“. U tekstu autor iznosi detalje o ubistvu Luburića i lamentira nad sudbinom ne samo Maksa Luburića, već i Anta Pavelića, kao i ostalih hrvatskih političkih emigranata koje je ubila jugoslovenska tajna policija: „U ovom slučaju izgubili smo dva Hrvata, dva suborca (Luburić i Pavelić - P. D.). U nedavnoj prošlosti, mnogo više. Neki su mrtvi, a drugi u neprijateljskim redovima (...) Teče hrvatska krv, koju proljeva hrvatski nož (misli se na Hrvate u službi jugoslovenskih organa bezbednosti - P. D.) za srbijanske dinare, a mi ne činimo ništa da to spriječimo." "13

Već naredna strana donosi tekst na sličnu temu. Članak predstavlja koncizan pregled izveštavanja nemačke štampe o tada aktuelnim likvidacijama hrvatskih političkih emigranata. Podvučeno je da su ubistva hrvatskih političkih emigranata u Saveznoj Republici Nemačkoj, zatim ubistva dvojice istaknutih srpskih emigranata u Parizu i Minhenu, te ubistvo Maksa Luburića u Španiji „Svratila veliku pozornost njemačke štampe, televizije i široke njemačke javnosti na zločinačko djelovanje jugoslavenske komunističke sigurnosne službe“. Tekstopisac Hrvatske države je različito ocenio izveštavanje nemačkih medija o ubistvima hrvatskih emigranata. Dok su komentari većine nemačkih listova ocenjeni kao objektivni, tekst Špigla o ubistvu Maksa Luburića opisan je kao „,neprijateljski“ i ,tendenziozan“. ${ }^{14}$

\footnotetext{
11 „Povodom tragične smrti V. Luburića“, Hrvatska država, maj-jun 1969.

12 Isto.

13 „Lanac UDB-inih zločina se nastavlja“, Hrvatska država, maj-jun 1969.

14 „Uznemirena javnost UDB-inim umorstvima“, Hrvatska država, maj-jun 1969.
} 
Osude i osporavanja politike Beograda prisutne su i u tekstovima koji se nisu bavili stanjem u Hrvatskoj, odnosno hrvatskom emigracijom. U članku „Crnogorci u odbrani svoje nacije“ kritikovana je odluka Matice srpske i Srpske književne zadruge da u okviru edicije „Srpska književnost u sto knjiga“ objavi i knjige crnogorskih autora (Njegoša, Marka Miljanova itd.). Konstatovano je da su „Srbi“ time „na najgrublji način zanijekali postojanje crnogorske književnosti, pa prema tome i crnogorske nacije kao takve“. Kritikovano je srpsko negiranje pojma „Crnogorac“, kao i, kako se u tekstu tvrdi, gledanje na Crnu Goru kao na deo „Velike Srbije“. ${ }^{15}$

„Jugokomunistička“ politika u Makedoniji oštro je napadnuta u tekstu pod naslovom „Crkveni aspekt spora u Makedoniji“. U članku se uz upotrebu pažljivo selektovanih istorijskih argumenata negira makedonski identitet stanovništva Makedonije, koje tekstopisac Hrvatske države naziva Bugarima. U tekstu se govori o „srbizaciji“ Makedonije u predratnom periodu, pri čemu se u odnosu komunističkog režima prema Makedoniji video kontinuitet sa makedonskom politikom predratnih vlasti: „Kako su se stvari dalje razvijale u bugarskoj Makedoniji pod srpskom vlašću poznato nam je svima kao savremenicima. Krvoločnost i brutalnost srpskih kolonizatora bugarske Makedonije nije ni malo zaostajala za turskim zulumćarskim metodama. Njihov plan odnarođavanja bugarskih Makedonaca nastavljen je u komunističkoj Jugoslavij, uz pomoć nekolicine domaćih regenata i izdajica, koji su školovani u Srbiji i sada zauzimaju ključne položaje u Partiji i UDBI za račun srpskih naredbodavaca, koji nastoje postići stare ciljeve posrbljavanja makedonskih Bugara pod makedonskim imenom. ${ }^{\text {" } 16}$

Ekstremno kritički odnos uredništva Hrvatske države prema svemu što je dolazilo iz Beograda delimično je ublažen u članku o knjizi Milovana Đilasa „Nesavršena država“. Đilasu se u tekstu priznaje posedovanje ,zavidne građanske kuraži“, ali se ističe da u svojoj kritici otkriva već otkriveno, ,jer je i vrapcima na krovu konačno - nakon toliko teškog iskustva - jasno, da je komunizam doživio slom u teoriji i praksi.“ Đilasu se u članku prigovara i navodna nekritičnost prema politici Beograda prema Hrvatskoj. Podvučeno je da o, ,pljački hrvatske imovine“, „odnarođavanju hrvatskog življa“ i ,otimanju hrvatskih zemalja“ Milovan Đilas „,mudro šuti“. ${ }^{17}$

Dok svi navedeni članci ilustruju uređivačku politiku Hrvatske države i pružaju uvid u politička razmišljanja uticajne organizacije hrvatskih političkih emigranata, nekoliko pasusa na šestoj strani analiziranog broja Hrvatske države naslovljenih sa „Upozorenje pretplatnicima, rasparčavaocima i čitateljima Hrvatske države" otkriva detalje o finansijskim problemima sa kojim se Hrvatska država suočavala. Konstatovano je da je Hrvatska država materijalno ugrožena, bu-

\footnotetext{
15 „Crnogorci u odbrani svoje nacije“, Hrvatska država, maj-jun 1969.

16 „Crkveni aspekt spora u Makedoniji“, Hrvatska država, maj-jun 1969.

17 „Nesavršeno društvo“, Hrvatska država, maj-jun 1969.
} 
dući da se izdržavala ,pretplatama, prodajom sa strane povjerenika-rasparčavaoca i privatnim doprinosima čitatelja, istaknutih hrvatskih rodoljuba“, pre čemu pretplatnici i distributeri nisu redovno izmirivali svoje obaveze. Tekst se zato završava apelom na patriotska osećanja čitalaca: „Sa praznim lupetanjem u prsa nije teško biti Hrvat. Hrvatstvo djelima pokazati baš sada, kad su naši neprijatelji uprli sve sile da likvidiraju nas osobno i čitavu hrvatsku štampu u Evropi! Radi toga, Hrvatice i Hrvati, pokažite svoju hrvatsku svijest ispunjavajući dužnost pretplate i slanja obračuna o prodaji lista! Pomažite Hrvatsku državu svakom zgodom dobrovoljnim doprinosima, jer pomagajući nju, pomažete glas Hrvata za vlastitom slobodom i nezavisnošću."18

$\mathrm{Na}$ stranama analiziranog broja Hrvatske države nema komercijalnog sadržaja. Izostavljene su čitulje, mali oglasi i reklame, ali i tekstovi zabavnog sadržaja, koji bi privukli širu čitalačku publiku. Takva koncepcija lista jasno ukazuje na nameru uredništva da Hrvatsku državu iskoristi za propadandu političkih stavova Hrvatskog narodnog odbora, pri čemu je ostvarivanje materijalne koristi bilo u potpunosti zanemareno. U sukobu hrvatske političke emigracije sa jugoslovenskim režimom propaganda je predstavljala ključno poprište sukoba. Otuda je Jelićeva organizacija nastojala da u tu svrhu iskoristi svaki delić resursa koji su joj stajali na raspolaganju.

Od članaka političkog sadržaja, objavljenih u broju 171-172 Hrvatske države, odudara samo tekst o pobedi Dinama nad Crvenom zvezdom u Beogradu. I ovde se, dakako, radi o jednom sasvim politički intoniranom tekstu, pri čemu se pobeda hrvatske ekipe doživljavala kao trijumf Zagreba nad Beogradom. U članku se sport jasno predstavlja kao jedno od polja političke borbe. Hrvatima je, prema tumačenju autora članka, to bio jedan od retkih prostora na kojima se mogao demonstrirati otpor politici beogradskim vlastima: „Male su mogućnosti ostavljene hrvatskom narodu u domovini, pod Udbinim terorom, da bi mogao dići svoj glas i organizirati svoj otpor (...) U kulturnom i slobodnom svijetu športska natjecanja nikad ne nose pečat političkih okršaja, no zato kod zarobljenih naroda, koji moraju živjeti pod terorom komunistićkih klika, na nogometnim i hokejskim utakmicama narod nalazi ventil kroz koji može dati oduška svom negodovanju protiv okupatora." Dinamo je pobedio sa 3:1. Zambata je dao dva gola, a tekstopisac Hrvatske države je beogradskoj ekipi preporučio promenu imena, ,jer ta $z$ vezda više ne sjaje, a pogotovu ne na hrvatskom nebu“. ${ }^{19}$

\footnotetext{
18 „Upozorenje pretplatnicima, rasparčavaocima i čitateljima Hrvatske države“, Hrvatska država, maj-jun 1969.

19 Isto.
} 


\section{Summary}

Dr Petar Dragišić

\section{The Analysis of Hrvatska drăava (May-June 1969) - the Organ of the Croatian People's Committee}

Key words: Hrvatska država, Croatian People's Committee, Yugoslavia, UDB

The end of WWII in Yugoslavia forced members of the defeated forces to seek refuge from the strong communist regime abroad. The emigration wave that lasted for several decades led to creation of numerous communities of political emigrants from Yugoslavia in Western Europe and overseas. Yugoslav political emigrants refused to reconcile themselves to the results of the war and tried by active propaganda activities, but also by employing more radical methods, to shake the regime in Yugoslavia. In the activities of political emigrants the Yugoslav authorities saw a serious menace to the country's stability so that the Yugoslav secret police strove to limit the activities of the émigré organizations.

One of the more active organizations of Croatian political emigrants was the Croatian People's Committee with seats in Berlin and Munich. The organization was headed by the prominent political emigrant in the Federal Republic of Gemany, Branko Jelić. One of the activities of the Croatian People's Committee was publication of the journal Hrvatska država.

The article analyses the number 171-172 for May-June 1969. In the article the texts in the journal are treated as historical sources of importance for reconstruction of ideas of one of the most influential organizations of Croatian political emigrants. The largest part of the contents of the analyzed number of Hrvatska država concern the texts dedicated to the anniversary of the foundation of the Independent State of Croatia (April 10), the murder of the Ustasha veteran Maks Luburić, as well as the situation in Yugoslavia. The authors of articles were extremely critical towards the policy of the Yugoslav regime, which was in keeping with the radical views of the Croat People's Committee.

The central part of the number is devoted to the speech of the leader of the Croatian People's Committee Branko Jelić at the celebration of the anniversary of the NDH in Munich that can be seen as the summary of the ideas and views of the organization he headed. In his speech Jelić criticized the alleged discrimination against the Croats, i.e. supremacy of the Serbs in Yugoslavia. Several texts were devoted to murders of prominent members of Croatian emigration, killed by their main rival - the Yugoslav secret police. 